\title{
THE INDISPENSABILITY OF THE BASIC SOCIAL VALUES IN AFRICAN TRADITION: A PHILOSOPHICAL APPRAISAL
}

\section{Macaulay A. Kanu}

\begin{abstract}
There are indispensable basic social values in African tradition which are for genuine development. The West in her own ways has attempted to jettison these values for theirs to take place, but in all, it is seen that theirs do not tally with the African society. Also, the Western aim is to render Africa dependent on them. The indispensability of African basic values presupposes that Africa has value system that is in consonance with her environment and conditions, and any way to displace it renders the society backward. These values are the guiding principles for genuine development which must remain indispensable to the Western values of colonialism, neo-colonialism and imperialism. With emphasis on these basic values by her leadership the future of Africa (and Nigeria in particular) will be of radical development.
\end{abstract}

\section{Introduction}

The question of value is akin to human society and activities. Every society has set of values, covering every aspect of human endeavour. These values are the guiding principles found in any society. Over years there have been the agitation and clamour for invigorating and maintaining durable and lasting positive values in Nigeria.

Like the West, Africa (and Nigeria in particular) has its own cultural values or value system. These values cover the whole ramifications of the society, and these values apparently play regulating roles in human relationship and also stabilizing factors of the society. Value system is the cultural outlook of the people and the understanding of the value system of the people is the understanding of the belief system and cultural system of the people in question. The questions arise, if every society has its value system why the campaign for maintenance of positive, durable and lasting values? Is our value system waning away in the face of threatening alien values of colonialism, imperialism and neo colonialism?

There is no gainsaying that our value system is in the process of 
decaying. It is an incontrovertible fact that the advent of colonialism and imperialism nearly caused a dethronement of our cultural pathway. This is why president Nyerere said:

Of all the crimes of colonialism there is none worse than the attempt to make us believe that we had no indigenous culture of our own, or that what we did have was worthless or something of which we should be ashamed, instead of being a source of pride. (Quoted in Akinpelu, 33).

The West (colonial masters) with the introduction of their educational system saw nothing of value in African culture. This led to crisis in our culture and value system. Crisis of a culture implies a process of development or degeneration introduced through a particular educational procedure. In the latter context, the West introduced an educational procedure which as a culture-transmitting process fashions out an attitude that neither respects the core values of our culture nor leads the younger members of the community to acquire the accumulated knowledge of the 'folkways' of their community with pride.

The educational process directed their minds and thought away from home cultures; equipping them with a type of education that is antagonistic to the African cultural traits and thought patterns. Writing in this direction Onwubiko said:

This is not surprising since the Western system of education was very well calculated to teach the new Africans that in order to rise in the ladder of the new culture and acquire the status it promised, they must be alienated, ideologically and physically, from their roottheir cultural past. The colonial agents presented themselves as symbols of human beings, in the image and likeness of whom all future generation Africans were to be created. (Onwubiko, xii).

However, the move was to some extent thwarted by nationalist leaders and writers who instead of acting in the new cultural 
situations reacted vehemently against it. this led to political independence which was thought to be a sure avenue to African cultural renaissance and development. Some African writers put defence for cultural preservation. These to some extent brought the African to the maxim "man know thyself". The intrigue by the West reared its cultural influencing head in the form of neo-colonialism.

Stemming from the adulteration and overthrow of our culture by colonialism, is the inferiority complex of dependency on foreign culture which is manifest in our unreflective and blind copy and introduction of alien values into our cultural milieu. This neocolonialism accounts for the subtle and gradual destruction of our value system. Hence, the call for the reconstruction of our value system. This is the call for reawakening of those positive traditional values that promote human dignity in our society. Before we go on cataloguing the values in the African value-system, we want to say as pointed out by N.K Dzobo:

That pervasive as religion and the divine is in the African belief-system, the African values are very practical and pragmatic: they are experiences hence they are man-centered and community centered. They are not based on divine revelation (as the Islamic and Christian religious values are); nor on a supposed rationality of man according to the Western mind). Rather, he said "they come from the flux of African life both past and present, with emphasis on past experience" (Dzobo: 76).

These values make a comprehensive system which gives African man a holistic outlook. The values are grouped as follows

(1) Moral values

(2) Religious and spiritual values

(3) Economic values

(4) Political values

(5) Aesthetic value

(6) Social values

Our point departure is the social values. Social values appears to be the bedrock of African cultural values as it tends to cover the other 
range of values subsumed under those values mentioned above.

\section{African Social Values and Their Functions in the Society}

It is an indubitable fact that there are enduring social values which inspite of the invasion and the encroachment of Western valuesystem remain the same. It is in this direction that Pantaleon Iroegbu wrote:

Contemporary African societies are in the betwixt and between of sitting on the deposition of tradition, values and life set-up, and in the invasion of the Western values of materiality over humanity value system .... Yet the African values are still consciously present. Most of them are still real in today Africa. They stand as witness to African development. Though the material may be low, the human is not. (Iroegbu: 83).

The implication of this quotation is that inasmuch as there is a context between the imported Western values and those of autochthonous African values, most social values remain unshakable. This is because African values are humanistic. These values take human person prior, central and end-point in technodevelopment valuations and engagements. We will discuss African (Nigerian) social values under the following

(a) Sense of good human relation

(b) Sense of community

(c) Sense of hospitality

(d) Sense of respect for authority and the elders

(e) Sense of extended family

(f) Sense of religiousity

\section{Sense of Good Human Relation}

The guiding principle of human relation in the African community is "live-and-let-live". This presupposes inter-personal and intercommunity relationship realized in the interaction between individuals of the same community and different communities. The relationship between individuals recognizes their worth as human beings and not only what they possess or what they can do for each 
other, even though these can come as later or secondary considerations in terms of reciprocity and in terms of interpersonal relationship. Help for one another is not based on immediate or an exact equivalent remuneration. Everyone is mindful that each person has something to contribute to his welfare, no matter the degree.

The arrangement of human relation is that of being one's brother's keeper or caring for each other's welfare. Every man is obliged to assist those who need help. The needy and the helpless are taking care of and assisted. It is in this perspective that Chieka Ifemesia wrote
A way of life emphatically centred upon human interest and values; a mode of living evidently characterized by empathy, and by consideration and compassion for human beings (Ifemesia, 2).

The art of dialogue and conversation is a cherished value in African relations. People freely discuss and express their problems and look for suggestions together. Expressing the importance of free and bonafide discussion in human relation, Onwubuiko stressed "the unwillingness to talk to people about either private or public affairs can be interpreted as bad manners or sign of enmity". (Onwubiko, 20). It is of note that the African believes that he who discusses his affairs with others hardly runs into difficulties or make mistakes in the execution of his plans.

However, there is accommodation and respect of individuals' sentiments, hence conversations that may cause misgivings are avoided. This is what the Yoruba people mean in their adage: "The fingers of a man who has only nine are not counted in his presence". In this perspective African sense of accommodation accounts for why:

In traditional African culture, the weak and aged; the incurable, the helpless, the sick were affectionately taken care of in the comforting family atmosphere (Okafor, 23).

\section{Sense of Community}


It has been pointed out by Onwubiko that the African idea of security and its value depend on personal identification with and within the community. The authentic African is known and identified in, by and through his community. In the economic sphere, the guiding principle for the economic arrangement is that of being one's brother's keeper or caring for each other's welfare, at least within one's immediate community. The basic principle of African social set-up is communalism.

Reacting against capitalism, individualism, exploitation and their concomitant class conflict, Nyerere of Tanzania pointed out that African communalism was a fundamental principle of the economic arrangements. A man is just as rich or poor as his community. Thus every man is obliged to work and contribute when he is able to, and to be provided for, as a matter of right, when he is no longer productive.

It is observed, that parasitism is not tolerated; whoever is capable of working but refuses to, or is lazy, will be allowed to starve there and then. The philosophy behind the African communalism, therefore guaranteed individual responsibility within the communal ownership and relationship. The prosperity of a single person, says an African adage, does not make a town rich. In other words, a person can only be truly safe in a community.

Land is a veritable factor in all economic considerations, the avenue to wealth and poverty. Hence, in its distribution, the communalistic principle was brought into play so that all ablebodied men could contribute their quotas, without excuse, and so that no group would be a landless peasantry looking up to some usually-absentee landlords for their daily bread as a permanent wage-earning class. This presupposes a communal system of land tenure, with the community or family head holding the land in trust for all members, born and as-yet-unborn. According to Akinpelu, "the allocation was strictly according to need and the ability of the individual to develop". (Akinpelu, 38).

In essence, we are saying that the community offers the African the psychological and ultimate security as it gives its members both physical and ideological identity. It must be noted that in the African mentality, the community as an entity remains, while individuals, as persons, come and go. Therefore, the African emphasizes 
community life and communalism as a living principle of which the basic ideology is community-identity. Its aim is to produce and present an individual as a community culture bearer.

\section{Sense of Hospitality}

Sense of hospitality is inherently indispensable in the currently survival African values. There is always spontaneous welcome and accommodation to strangers and visitors. Africans easily incorporate strangers and give them lands to settle hoping that they would go one day, and the land would be reverted to the owner. This is usually done with the belief that one will never opt out of his own community.

Unlike the West, no appointment and special invitation are needed for one to visit a distant relation or neighbour. On arrival, once there is food the visitor is invited to eat. He is treated kindly, just as one would wish to be treated when visiting another home.

Africans have symbolic ways of expressing welcome. These are in forms of presentation of kola nuts, traditional gin, coconuts, cohise chalk etc. in various communities. These are given to show that he is welcome and safe. Onwubiko has noted that among the Igbo, the basis of hospitality is that "a guest must not harm his host and that when he departs, he should not develop a hunch back on the way home". (Onwubiko, 23).

Another aspect of hospitality which is highly cherished is sharing with a needy neigbour who comes for assistance. Anybody who has and does not assist is taken to be a bad fellower.

\section{Sense of Respect for Authority and Elders}

Sense of respect for authority and elders helps to solder and smoothen social relations in African society. Before advent of slavery, slave trade and colonialism there was stability, peace and harmony in any African setting.

There was the deep respect for legitimate and constituted authority, be it that of head of the family or of the Oba, Obi or Emir. This authority is hierarchical but democratic, in the sense that I remains legitimate and sacred only for as long as it continues to be exercised in the interest of the governed, and in accordance with the time-honoured and sanctified customs and traditions of the people. It 
should be pointed out that the obedience is not to the person of the Oba or Emir as an individual, but rather to the institution, and abuse of it, disobedience becomes legitimate and the culprit is made to bow out. In Yoruba land, suicide was an honourable way of doing so, so much was regard for peace, stability and orderliness as political values that the individual life could be sacrificed to maintain the integrity and inviolability of the institution.

It is natural for Africans to respect an elder. The way the young ones salute the elders was, and still is regarded as evidence of morality or lack of it, instead of as a matter of etiquette. In Yoruba setting a young man is described as totally immoral simply because he would not prostrate for his elders.

The importance of respect for elders is seen in the Igbo saying; "He who listens to an elder is like one who consults an oracle". The oracles are believed to give the infallible truths, thus the elders are also believed to say the truth and the words and instructions are heeded to for the promotion of good behaviour among the young.

The elders are taken to be repository of communal wisdom and therefore they are conceded leadership in the affairs of the people. The respect given to the elders has its practical affect in the maintenance of custom and tradition. The young are always looking forward to being elders and they are often told that if a child respects an elder, he would be respected by the young when he becomes an elder.

\section{The Sense of Extended Family}

According to Pantaleon Iroegbu "African languages generally have no words for uncles, aunts cousins and nieces. All these are part of the one family. The family is one, but extended". (Iroegbu, 84).

Marriage is taken as a good and serious thing in the sense that it is a covenant between two (extended) families, kindreds and villages. The extended family system is very much alive in contemporary Africa inspite of the wave the Western value system is making. It is a conflict-and-crises-resolution ocean.

"Living together" and the sense of "community of brothers and sisters" are the basis of, and the expression of, the extended family system in Africa. The rationale behind it is that balance of kinship relations, seen as essential to the ideal balance with nature that was 
itself the material guarantee of survival, called for specific conduct.

It should be pointed out that the most admired value in the traditional African economic arrangements is the social security or economic insurance guaranteed by the social organization typified by extended-family system. The security is not just for the old age, but also for the poor and disadvantaged members of the family, who have been seen to have made efforts but have not been successful. Children of such unsuccessful adults are a legitimate economic charge on the wealth of the luckier members. In other words, the comforting family atmosphere is provided by the extended family system. It is a system that ultimately anchored and still rests on the philosophy of "live-and-let-live". It is a principle which defines rights and duties, responsibilities and obligations towards the less fortunate, those incapacitated in one way or another. For instance, a man has the obligation to cater for the widow and orphans of his dead relative. Failure to do this earns him strong public opprobrium and as a result, it is difficult to find someone in the community without help. In essence, extended family is a veritable instrument in the family cohesion and community continuity and stability.

\section{Sense of Religion}

Africans are deeply religious, for African life is religion and vice versa. The attachment to and worship of God, form a dominating part of their world view. All they do or say and permit is impregnated with a vision of the divine, and all natural reality is explainable in function of the supernatural.

African social values rest on the moral values which in turn rest on religious values. To many people it is perverse and perhaps sacrilegious to separate the moral and the religious values; if separable at all, religious values are more fundamental and undergird the moral values. It is the presence of religion that lends meaning and authority to values. The sense of religion which is our spiritual selves is that of instinctive feelings of oneness with the divine, or our longings for, and intimations of immortality. Religious or spiritual element in African man characterizes our relation with the divine, with God and/or the gods. And it is an indubitable fact that this sense of religion is promotion of moral excellence.

It is the sense of religion that naturally endowed man with 
respect for human life and human dignity. According to Akinpelu "such a respect definitely lacks depth and authority if based simply on moral considerations or moral arrangements between men, except, of course, if the morality is conceived as one and the same with religion in the first instance". (Akinpelu, 37).

The importance of religion to social relationship is emphasized when you compare Western European values with African values. To the Western European, there is nothing immoral to consign their old and helpless relations to the Old People's Homes. That might even seem more human than to abandon them. But to the African mind, even that so-called humane treatment is a betrayal of the fundamental assumption behind the Western man's idea of man's worth-namely, that a man is deserving of respect or is of worth only, and in so far as, he is virile and productive, when he is no longer so, the next human thing is entrust his welfare to institution officers and caretakers. That is an abomination to the African mind. The care of the aged, as an African institution, is situated within the family.

It is so cherised and so organized that there is no need, in the African setting, for the cheerless nursing homes for the aged as exist today in Europe and America. The idea of old people's Home and its introduction into Africa would lead to the abuse of the African sense of and respect for old age. It is a common belief among Africans that the older they are, the greater the respect and care, because the nearer they are to the point of becoming spiritual entities which is the continuity of existence, only at a different level of conception. Hence, the spiritual element runs deep in the personal and interpersonal value system of the African.

\section{Conclusion}

The social values enumerated above are manifestations of African humanism. These values have survived the Western cultural adulteration by colonialism. African social values centre around human worth and form a comprehensive system which has behind it some identifiable metaphysical beliefs about man and his world. For instance, man in African traditional culture is not just an individual who 'contracts' to live with others in society, and presumably opts out if the balance of advantages is no longer favourable. Rather the African man is first and foremost a member of his family, the 
extended family, the community and his society in that order before being an individual. According to Lambo, "the Africans find it difficult to conceive a man as a purely contemplative being: for them human qualities presuppose a world of human relations. Thus the influence of group consciousness is recognized as the motivating idea and thought" (Lambo, 127).

Lambo's statement presupposes the social and communal nature of African man as against the individualism of the West. There is a metaphysical belief in the superiority of claims of the family and the community over the individual which re-echoes throughout the various values that we have considered here.

African social values are both man-centred and communitycentred. This being the case, it is not a surprise that human dignity and the respect for human life are of supreme importance. The social values are tailored to ensure a man's tenure of life, right from birth until old age. These social values considered are ingrained in African personality, that they are taken as mirrors for our authencity as Africans. The enduring nature of these values, inspite of cultural upheaval engendered by colonialism is as a result of the inherent humanism associated with them. Any one who casts reflection on the ways of speaking about these social values is bound to be struck by the pre-occupation with human welfare. For an African, what is morally good is what befits a human being, it is what is decent for man-what brings dignity, respect, contentment, prosperity and joy to man and his community. These social values enhance and safeguard.

We must point out that it is anthropologically fallacious to say that Western European values have destroyed the whole of African culture. This is practically, not possible. European value system is in Europe and stays there. African value system is in African and is consciously present here. What come into contact are elements and products of cultures, which in spite of their influence have left some African social values undiminished.

The infiltration and adoption of certain Western values into our system have brought abnormality in our society. That is why the present social dispensation in some parts of our society is antihuman. This is manifest in the promotion of individualism and self interest as against communalism and brotherly love. The introduction of such Western values into the political and economic 
arenas has rendered the society backwards. Lives are seen as competitions. The "love your neighbour as yourself" which is the background of our value-system has been relegated to nothingness. Instead of progressing, African society like Nigeria is going backwards. Man is seen as a threat to one another. For there to be progress and development, African value system must be promoted by the leadership. Falling into and copying of Western values will only destroy humanity as they are strange to the philosophy of humanism which is the basis of African value system. We therefore advise that we should jealously guard these values because they give us a character that is distinctively and uniquely African. 


\section{References}

Akinpelu, J.A. "Values in Nigerian Society" in New Perspectives in Moral Education. Otonti A. Ndubuka and E.O. Iheoma (Eds) Ibandan: Evans Brothers, Nigerian Publishers Ltd 1983).

Anyanwu, K. "The Idea of Art in African" in Contemporary Philosophy: A New Survey in West African Philosophy Vol. 5 E. G. Floistad (Ed.), Boston: Martians Nijhoff Publishers, 1987.

Asouzu, I. I. Effective Leadership and the Ambivalence of Human Interest: The Nigerian Paradox in a Contemporary Perspective. Calabar: University of Calabar Press, 2003.

Awolalu J. O. and P. A. Dopamu. West African Traditional Religion. (Ibadan: Onibonoje Press and Book Industries,1979.

Dzobo, Quoted by Akinpelu, J.A "Values in Nigerian Society" in New Perspectives in Moral Education. Otonti A. Ndubuka and E.O Iheoma (Eds) Ibadan: Evans Brothers, 1983.

Ifemesia, C. Traditional Humane Living Among the Igbo Enugu: Fourth Dimension Publishers, 1979.

Irele, D. In the Tracks of African Predicament. Ibadan: Option Books and Information Services, 1993.

Iroegbu, P. Enwisdomization and African Philosophy. Owerri:

International Universities Press, 1994.

Mbiti, J. S. Introduction to African Religion. London: Heinemann Educational Books, 1975.

Okafor, F. C. Africa at Crossroads. New York, 1974.

Onwubiko, O. A. African Thought, Religion and Culture. Enugu: Bigard Memorial Seminary, 1991. 